\title{
ESCHATOLOGY, ECOLOGY, ECONOMICS IN MEMORY OF ENZO TIEZZI
}

\author{
HERMAN E. DALY \\ Professor Emeritus, School of Public Policy, University of Maryland.
}

The subject of my essay in honor of our kind friend and colleague, EnzoTiezzi, requires a bit of explanation - not the parts about ecology and economics, which were areas of our common interest and work. But to consider them in the context of eschatology may seem odd. First, Enzo and I never discussed eschatology or theology at all, so I should make it clear that I am not attributing any particular beliefs to him. But he was an honest and thoughtful man, and I regret that I never took the initiative to ask his views on such ultimate questions. The death of a good friend, born in the same year as one's self, focuses the mind on the doctrine of 'last things'. So these are my reflections stimulated by remembrance of Enzo - thoughts I wish I could discuss with him, and argue about, over a bottle of Chianti from his own vineyard in his beloved Sienna. Maybe other friends of Enzo actually had such a conversation with him and will share it.

Eschatology is not the most popular field of theology. It deals with last things, the end of time and creation - not something of which we have any experience, so it is more an expression of hope than knowledge. Many Christian theologians believe that our hope, both individual and collective, ultimately lies in the New Creation (Rom 8), which will be God's act at the end of the present creation (Jurgen Moltmann, Richard Bauckham, N.T. Wright, John Polkinghorne). One thing that science and Christianity agree on is that the present creation will ultimately die. The model for thinking about forever (whether personally or cosmically) is death and resurrection - New Creation, not perpetuity for the present creation, which would be both a scientific and a Christian heresy. Perhaps the cosmology of a 'big crunch' followed by another big bang is to some extent an analogous secular eschatology. But New Creation in Christian theology will be a miracle, as was the first act of creation, or as the first fruit of the New Creation witnessed in the Resurrection. This doctrine is not emphasized from mainline pulpits today, perhaps from legitimate fear of identification with apocalyptic sects, left-behind rapture theology, end-of-the-world fanaticism, and the frightening prospect of final judgment. Nevertheless, we liturgically recite the mystery of the faith, 'Christ has died; Christ is risen; Christ will come again'. Some fundamentalists put great emphasis on 'coming again', but the mainline Protestants have little to say about it.

I will let the theologians sort out the conflicting eschatologies of different branches of Christianity [1], and of other religions (including scientism), and for now simply ask a question that I think would have interested Enzo: what does the Christian belief in New Creation just outlined have to do with how we act in the world - specifically with the current economic/ecological crisis $[2,3]$ ? I focus on Christianity because of my limited knowledge, and leave discussion of other religions' eschatology to those better informed.

In God's New Creation death and decay, finitude and evil will, it is expected, be overcome. In the present creation they remain very real, built into its fundamental structure. We think that by building a modern Tower of Babel of unending economic growth and progress, we will reach heaven on earth, or maybe in space, and at least as a species escape death, decay, time, and entropy within the present creation. Furthermore, the secular intelligentsia assures us that the present creation is all there is or ever will be, and in any case it is no longer considered a miracle, but the product of 'Chance' - not 
Creation but 'Randomdom' without any purpose. We now understand this random evolutionary process and can control it in our quest for heaven on earth via genetic engineering, space colonization, and economic growth. Of course if we can control evolution it will no longer be random, inconveniently removing the principle on which our understanding of it was based. Scientists were always a bit embarrassed by so much appeal to chance, and would be pleased to offer a moral criterion by which to choose our direction. But it is hard for them to appeal to a 'moral compass' while denying any 'magnetic north', any objective value that lures us toward itself. So let GDP growth be a proxy for magnetic north, they say, since that is what all nations in fact put in first place. And GDP at least includes the goods of food, clothing, and shelter, which many still need - never mind the un-subtracted 'bads' and the mistakenly added 'anti-bads'.

This idolatrous tower has collapsed before, and is badly out of plumb now. The basic reason is that, as creatures, we share subjection to entropy and finitude with the rest of this creation of which we are a part. Contrary to the dictates of Randomdom, Christianity teaches that we are also made in God's image and charged with dominion and responsibility for this creation - but as mere creatures, and fallen ones at that, are not put in charge of constructing the New Creation. The current loss of faith in the New Creation has contradictory implications for economic and environmental policy. On the one hand people (many scientists) may argue that this creation is all there is, so we better not undermine the intense seriousness of caring for it by allowing ourselves to hope for another gift, - a New Creation, after we have trashed this one. Be grateful for the present gift and care for it while it lasts. On the other hand, without faith in the Creator, and the promise of ultimate renewal, we are irresistibly tempted to try to build a 'new creation' ourselves, and that seems to mean a modern Tower of Babel and the economic growth that supports it. As IBM forthrightly puts it in their advertisements, 'let's build a smarter planet'. They do not say: 'let's make a smarter adaptation to the Earth from which we were created and by which we are sustained'. We are urged to change the planet, not ourselves! Such techno-fantasies may constitute a secular eschatology that substitutes for the religious ones.

The net destructive consequence of the current scale and growth of the economy for the present creation that sustains it is greatly downplayed, if not totally ignored. Death, decay, and entropy are permanent features in the present creation, and without faith in the New Creation, what final purpose is there beyond 'eat, drink, and copulate, for tomorrow we dissipate'? We may well improve the material and social conditions in which we carry out these activities, and make it last a bit longer, but it all finally still dissipates unless there will be a radical renewal of the basic nature of creation. And who can renew creation other than the Creator?

Our attempt to reach heaven on earth by economic growth has led to the wholesale physical transformation of the earth into ourselves and our furniture - with ever less remaining for future generations and for other species. In my and Enzo's lifetime, world population has more than tripled, and the populations of livestock, cars, houses, toasters, cell phones, etc. have vastly more than tripled. These are all 'dissipative structures', to use Prigogine's term, and they depend on environmental depletion and pollution for maintenance and replacement, much as human bodies do. The world has moved from empty to full - full of economy and empty of ecology. Remaining natural capital has now replaced man-made capital as the limiting factor in production. The fish catch is no longer limited by fishing boats, but by remaining fish and their habitats. Barrels of pumped crude oil are no longer limited by drilling and pumping capacity, but by remaining deposits, and perhaps more stringently by capacity of the atmosphere to absorb the $\mathrm{CO}_{2}$ from burning the oil. But absorptive capacity is also natural capital. Sometimes sources are more limiting - sometimes sinks.

Yet the World Bank expects a four- to five-fold increase in the size of the world economy by 2050 [4], and is eager to help this happen. They do not tell us by how much they expect the earth to 
grow by 2050 ! The social and environmental costs of the Tower of Babel are already growing faster than the production benefits, making us poorer not richer. Such uneconomic growth will not help the poor, yet we keep claiming otherwise. We hide the truth from ourselves by faulty accounting (treating natural capital consumption as income, adding rather than subtracting defensive expenditures), and by issuing mountains of debt, liens against the projected growth of real wealth that is unlikely ever to happen, but in which we put our faith. We misleadingly refer to these debts as 'assets', or with slightly less dishonesty as 'troubled assets' when they become devalued by the common sense realization that growth cannot redeem them. And then we make bets on which debts will be repaid and which will not. Those bets, incredibly, are then counted as additional assets!

Why this mad refusal to face reality? I think the answer is distressingly simple within the context of our present assumptions. Without growth the only way to cure poverty is by sharing. But redistribution is political anathema. Without growth to push the hoped for demographic transition, the only way to cure overpopulation is by population control - a second anathema. Without growth the only way to invest in environmental repair is by reducing current consumption - third anathema. Three anathemas and you are out. Even if current policy manages to jump-start the growth economy for another round, we will soon enough have to move from a failed growth economy to a steady state economy - from idolatrous efforts to build a substitute 'new creation' on our own, to humble stewardship and sharing of the present creation - sharing it with the poor, with future generations, and with other species.

This stewardship of the present creation would not be the New Creation, but a partial, hopeful anticipation of it reflected back into the present order. The consequence of the current lack of eschatological hope, the secular belief that this creation - nay, randomdom - is all there is or ever will be, is to get as much as you can while it and you last. Even our higher ethical impulse to love and care for others in the present creation is undercut by the ultimate futility of random luring us more rapidly toward its cold meaningless dissipation. Far from being an escape from present problems, eschatological hope for the New Creation is necessary to sustain both technological and political efforts to care for the gift of God's present creation. The New Creation will be a mysterious transformation of the present creation, we are told - somewhat like a tree is the transformation of a seed. Although the New Creation is God's act, not ours, it is the hopeful context in which our seed-saving actions can have ultimate meaning. Although emphasis in the New Creation theology is sometimes on the discontinuity with the present, there is also recognition of continuity - something from the old creation is transformed into the new, perhaps the broken pieces of our best efforts. And without a hopeful vision of the new, we are left with the losing game of 'transforming' the old by our own efforts, with nothing but lame technological Gnosticism to confront the power of entropy, finitude, and evil. But as heirs to the New Creation, we are empowered to a limited degree to also be its proleptic agents, or maybe just its welcoming committee.

As stated earlier, science and Christianity agree that the present creation, like we ourselves, will die. Without eschatological hope in New Creation we are left with, at best, an increase in longevity of the present creation, the much-discussed, though ill-defined, goal of 'sustainability'. Although that is a good thing (Enzo worked for it, and so do I), is it enough to inspire the enormous countercultural effort required to bring about even this restricted purpose? Christian belief in the imago Dei requires us to exercise our limited dominion over creation as its steward. But faith in the New Creation saves us from despair over our repeated failures, as well as over the ultimate impossibility of our preserving this Creation in the very long run.

Most scientists will not be happy with talk about miracles, with hope in the New Creation. Yet when faced with the ultimate heat death of the universe, and the meaninglessness implicit (and increasingly explicit) in their materialist cosmology, some scientists seem to flinch, and look for 
optimism somewhere within their materialism. They invent the hypothesis of infinitely many (unobservable) universes in which life may outlive our universe. They were led to this extraordinary idea to escape the implications of the anthropic principle - which argues that for life to have come about by chance in our single universe would require far too many just-so coincidences. To preserve the idea of chance as credible cause, and thereby escape any notion of Creator or Telos, they argue that although these coincidences are indeed overwhelmingly improbable in a single universe, they would surely happen if there were infinitely many universes. And of course our universe is obviously the one in which the improbable events all happened. If you don't believe that Shakespeare wrote Hamlet, you can claim that infinitely many monkeys pecking away at infinitely many typewriters had to hit upon it someday.

Unfortunately the evidence for infinitely many universes, or monkeys for that matter, is nonexistent. Likewise, the only 'evidence' that could be offered to support hope for a future miracle would be the occurrence of a similar miracle in the past. That of course would be the Creation itself. Science rightly tries to account for this Creation, as far as reasonable, in its own materialist terms, and of course rejects 'miracle' or God as an explanatory category. Whether ad hoc postulation of infinitely many unobservable universes qualifies as a reasonable explanatory category, I will leave to the reader's judgment.

The working hypothesis of scientific materialism, however fruitful it has been, should not be confused with an Ultimate Metaphysics of Chance. Nor does adding Darwinian natural selection to Mendelian random mutation mitigate the dominance of chance, since the selecting criterion of environmental conditions (other organisms and geophysical surroundings) is also considered to be a random product of chance. Mutations provide random change in the genetic menu from which natural selection picks according to the survival odds determined by a randomly changing environment.

This Metaphysics of Chance precludes explanation of some basic facts that, however, will not be silent: first, there is something rather than nothing; second, the just-right physical 'coincidences' set forth in the anthropic principle; third, the 'spontaneous generation' of first life from inanimate matter; fourth, the accumulation of an incredible amount of specified information in the genome of all the irreducibly complex living creatures that evolved from the relatively simple information in the first living thing (presumably by random change - ignoring that random destroys rather than creates information); fifth, the emergence of self-consciousness and rational thought itself (if my thoughts are ultimately the product of random why believe any of them, including this one?); and sixth, the innate human perception of right and wrong, of good and bad, which would be meaningless in a purely material world. Chance surely plays an important role in our world, but explaining all these facts 'by chance' strains credulity at least as much as 'by miracle'.

Metaphysical humility in the face of ignorance and mystery, one of Enzo's many good qualities, remains a virtue in both science and philosophy.

\section{REFERENCES}

[1] Wilkinson, D., Christian Eschatology and the Physical Universe, T.T. Clark International: London, 2010.

[2] Bridger, F., Ecology and eschatology: a neglected dimension. Tyndale Bulletin, 41(2), pp. 290-301, 1990.

[3] Moo, D.J., Nature in the new creation: new testament eschatology and the environment. Journal of the Evangelical Theological Society, 49, pp. 449-488, 2006.

[4] Daly, H., Growth and development: critique of a credo. Population and Development Review, pp. 511-518, September 2008. doi:http://dx.doi.org/10.1111/j.1728-4457.2008.00234.x 